\title{
STUDY OF IN VITRO ANTI-LITHIATIC EFFECT OF IPOMOEA BATATAS (L) LEAVES AND TUBEROUS ROOTS
}

\author{
SATHISH R*, JEYABALAN G
}

Department of Pharmacy, Sunrise University, Alwar, Rajasthan, India. Email: rsvsathish2000@yahoo.co.in

Received: 28 October 2017, Revised and Accepted: 25 November 2017

\begin{abstract}
Objective: The present study was to demonstrate the in vitro anti-lithiatic effect of Ipomoea batatas (Convolvulaceae) leaves and tuberous roots.

Methods: The obtained ethanolic extract of I. batatas leaves and tuberous roots (EIBL and EIBR) and aqueous extract of I. batatas leaves and roots (AIBL and AIBR) were used for this in vitro study. The dissolution method of calcium oxalate by titrimetry method and calcium phosphate by colorimetric method was studied. Nucleation and aggregation of calcium oxalate crystals were determined by a spectrophotometric assay.

Results: In the estimation of calcium oxalate by titrimetry method, the I. batatas leaves and roots have very significant (p<0.01) capability to dissolve calcium oxalate. Percentage dissolution of calcium oxalate crystals was found to be 37.53\%, 22.74\%, 39.74\%, and 24.28\% for EIBL, AIBL, EIBR, and AIBR, respectively. In the estimation of calcium phosphate by colorimetric method, the percentage dissolution of calcium phosphate crystals by EIBL, AIBL, EIBR, and AIBR was found to be $67.15 \%, 43.17 \%, 76.74 \%$, and $47.96 \%$, respectively. The $I$. batatas leaves and roots were significantly $(\mathrm{p}<0.01)$ dissolved calcium phosphate also. The results were clearly shown that $I$. batatas extracts significantly ( $<<0.01)$ inhibited both nucleation and aggregation of calcium oxalate crystals by concentration-dependent manner. The maximum percent inhibition of calcium oxalate nucleation by EIBL, AIBL, EIBR, and AIBR was found to be 59.09\%, 50.0\%, 84.09\%, and 47.73\%, respectively, at 1000 g/ml. The EIBL, AIBL, EIBR, and AIBR were inhibited calcium oxalate aggregation by $63.46 \%, 36.54 \%, 84.61 \%$, and $42.3 \%$, respectively, at $1000 \mu \mathrm{g} / \mathrm{ml}$.
\end{abstract}

Conclusions: The results clearly indicate that I. batatas leaves and tuberous roots were found to express in vitro anti-lithiatic potential.

Keywords: Anti-lithiatic, Calcium oxalate stones, Crystal nucleation and aggregation, In vitro Anti-lithiatic, Ipomoea batatas, Kidney stones.

(C) 2018 The Authors. Published by Innovare Academic Sciences Pvt Ltd. This is an open access article under the CC BY license (http://creativecommons. org/licenses/by/4. 0/) DOI: http://dx.doi.org/10.22159/ajpcr.2018.v11i2.23319

\section{INTRODUCTION}

Urolithiasis, also called renal calculi, is common and an extremely painful condition with recurrent stone formation which is also associated with risk of renal damage. Kidney stone formation is a complex process and it results as a cascade of events, including crystal nucleation, growth, aggregation, and crystal retention within the renal tubules [1]. Usually, kidney stones are yellow or brown with a smooth or gagged structure. Some common types of kidney stones are calcium oxalate, calcium phosphate, struvite, uric acid, and cysteine, among of which calcium stones are the most common kidney stones in both humans and rats [2]. Urolithiasis has afflicted humankind since antiquity and can persist, with serious medical consequences, throughout patient's lifetime, with a recurrence rate of $70-80 \%$ in males and $47-60 \%$ in females. The current medical management of lithiasis is either costly or not without side effects. Extracorporeal shock wave lithotripsy is widely used for the treatment of urolithiasis and its multiple sessions in recurrent stone formation may cause chronic renal failure. The various therapies including thiazide (diuretic) and alkali citrates are used to prevent the recurrence of hypercalciuria and hyperoxaluria, which induce calculi formation, but evidence for their efficacy is less [3-5]. Therefore, there is a need to establish medical treatment to prevent recurrent stone formation. Nature is the best combinatorial chemistry and has possible answers to all diseases for humankind. The undesirable effect of the modern medicine has already diverted the attention of the people toward herbal medicines. To increase the acceptability and awareness among the people, there is an urgent need to develop trust and faith toward the safer indigenous system by establishing its validity in the treatment for various diseases [6]. Indigenous plants have been used as a potential source of medicine since ancient times. There are more than 13,000 plants have been studied for the various diseases and ailments all over the world in the past few years [7]. The
World Health Organization has shown great interest in documenting the use of medicinal plants from the tribals residing in various parts of the world. Ipomoea batatas belongs to the family Convolvulaceae; commonly known as sweet potato is the sixth most important food crop in the world. Sweet potato roots are a good source of carbohydrates, while leaves and stems contain additional nutritional components in much higher concentrations than in many other commercial vegetables. Ethnopharmacological data have shown that sweet potato has been effectively used in herbal medicine to treat inflammatory infections, diabetes, oxidative stress, viral infection, and oral diseases. Recently, studies on sweet potato have focused on its antioxidant capacities due to the increased content of phenols, flavonoids, $\beta$-carotene, anthocyanins, and caffeoylquinic acid derivatives [8-11]. The sweet potato roots are sweet, refrigerant, laxative, aphrodisiac, diuretic, and tonic. They are useful in vitiated conditions of pitta, burning sensation, hyperdipsia, constipation, strangury, renal and vesicle calculi, diabetes, and general weakness [12]. The sweet potato is using as traditional medicine against renal calculi, diabetes, and general weakness by the village peoples of Thoppampatti, Dindigul district, Tamil Nadu, India [13]. I. batatas (Sakarkand alu) tubers are traditionally given against renal calculi in the districts of West Bengal [14]. It is thus our duty to establish the pharmacological effect of this eco-friendly medicinal plant for the removal of human suffering and miseries from kidney diseases. Hence, this study has evaluated the in vitro anti-lithiatic effect of I. batatas leaves and tuberous roots.

\section{METHODS}

Plant materials collection and extraction

The fully matured dark green leaves and fresh tuberous roots of I. batatas (L) lam were collected from the Vadipatti and Dindigul areas, Tamil Nadu, India, in July 2015. The plant was identified and 
authenticated by Dr. D. Stephen, Taxonomist, American College, Madurai. The dust-free leaves and sliced tuberous roots were allowed to dry under shade in the laboratory for 20 days. About $1000 \mathrm{~g}$ each of pulverized leaves and tuberous root powders were placed, and solvent such as ethanol and water was added individually in the flat bottom flasks. The mouth of flasks was covered with aluminum foil and kept in room temperature for 7 days to dynamic maceration with occasional shaking. The extracts were filtered using Muslin cloth followed by Whatman no 1 filter paper and finally filtered using vacuum and pressure pump. The solvents from the extracts were removed using rotary vacuum evaporator and concentrated under reduced pressure of $300-500 \mathrm{mmHg}$ at $50-60^{\circ} \mathrm{C}$ [15]. The obtained semi-solid residues of aqueous and ethanolic extracts of leaves and tuberous roots henceforth called ethanolic extract of $I$. batatas Leaves (EIBL), aqueous extract of $I$. batatas leaves (AIBL), ethanolic extract of $I$. batatas tuberous roots (EIBR), and aqueous extract of I. batatas tuberous roots (AIBR). All the extracts of I. batatas (EIBL) were intended for preliminary phytochemical evaluation [16].

\section{Evaluation of in vitro anti-lithiatic activity by dissolution method}

\section{Preparation of semi-permeable membrane from eggs}

Apex of eggs was punctured to remove out the entire content, and empty shells were washed thoroughly with distilled water and then placed in a beaker containing $4 \mathrm{ml}$ of concentrated $\mathrm{HCl}$ in $200 \mathrm{ml}$ distilled water. It was kept overnight for decalcification process; on the next day, semipermeable membrane was removed carefully, washed thoroughly with distilled water, and placed it in ammonia solution for neutralization of acid traces. Finally, semi-permeable membrane was rinsed with distilled water, stored in refrigerator, and used for calcium oxalate and calcium phosphate dissolution methods [17].

\section{Dissolution method of calcium oxalate}

\section{Synthesis of calcium oxalate by homogeneous precipitation}

Exactly $1.47 \mathrm{~g}$ of calcium chloride dihydrate was dissolved in $100 \mathrm{ml}$ distilled water and $1.34 \mathrm{~g}$ of sodium oxalate was dissolved in $100 \mathrm{ml}$ of $2 \mathrm{~N}$ sulfuric acid. Equimolar prepared solutions of calcium chloride dihydrate and sodium oxalate were allowed to react in a beaker to precipitate out calcium oxalate with stirring. The resultant calcium oxalate precipitate was freed from traces of sulfuric acid by ammonia solution, washed with distilled water, and dried at $60^{\circ} \mathrm{C}$ for $2 \mathrm{~h}$ [17].

\section{Estimation of calcium oxalate by titrimetry method}

As per experimental design, dissolution studies of calcium oxalate were carried out in six groups; one group served as negative control (Group I) which consists of $1 \mathrm{mg}$ of calcium oxalate alone, weighed exactly $1 \mathrm{mg}$ of calcium oxalate and packed along with $10 \mathrm{mg}$ of cystone (removing color coating and crushed into powder form) as standard group (Group II). In test groups (Groups III-VI), $10 \mathrm{mg}$ each of test substances EIBL, AIBL, EIBR, and AIBR were packed along with $1 \mathrm{mg}$ of the calcium oxalate. All groups were packed as above in separate egg-based semipermeable membranes tied with thread by suturing at one end. Now, the materials packed in semipermeable membranes were allowed to suspend in separate conical flasks containing $100 \mathrm{ml}$ of 0.1M TRIS buffer. Another end of the thread was tied on the mouth of conical flasks and covered with aluminum foil. The conical flasks of all groups were kept in an incubator, preheated to at $37 \pm 1^{\circ} \mathrm{C}$ for $7 \mathrm{~h}$. After $7 \mathrm{~h}$, flasks with membrane were kept in magnetic stirrer for $5 \mathrm{~min}$. Finally, all the membranes were taken out of the flask and content of each membrane was collected in different test tubes by removing the sutures. $2 \mathrm{ml}$ of $1 \mathrm{~N}$ sulfuric acid was added to each test tube and titrated with $0.9494 \mathrm{~N} \mathrm{KMNO}_{4}$ till a light pink color end point obtained. $1 \mathrm{ml}$ of $0.9494 \mathrm{~N} \mathrm{KMNO}_{4}$ is equivalent to $0.1898 \mathrm{mg}$ of calcium. The amount of undissolved calcium oxalate is subtracted from the total quantity used in the experiment in the beginning, to know how much quantity of calcium oxalate was dissolved by the test substances. There is inverse relationship between the dissolution of calcium oxalate and concentration of calcium ions in solutions [17-19]. Each treatment was repeated 3 times and volume of standard $\mathrm{KMNO}_{4}$ was expressed as mean $\pm S D$. The percentage dissolution of calcium oxalate in various groups was calculated.

\section{Dissolution method of calcium phosphate}

Synthesis of calcium phosphate by homogeneous precipitation About $1.47 \mathrm{~g}$ of calcium chloride dihydrate was dissolved in $100 \mathrm{ml}$ of distilled water and $1.42 \mathrm{~g}$ of disodium hydrogen phosphate was dissolved in $100 \mathrm{ml}$ of $2 \mathrm{~N}$ sulfuric acid. Equimolar prepared solutions of calcium chloride dihydrate and disodium hydrogen phosphate were allowed to react in a beaker to precipitate out calcium phosphate with stirring. The resultant calcium phosphate was freed from traces of sulfuric acid by ammonia solution, washed with distilled water, and dried at a temperature $60^{\circ} \mathrm{C}$ for $2 \mathrm{~h}$ [17].

\section{Preparation of reagents}

Molybdate sulfuric acid reagent was prepared by $5 \% \mathrm{w} / \mathrm{v}$ of sodium molybdate solution, $13 \mathrm{ml}$ of concentrated sulfuric acid in $80 \mathrm{ml}$ of distilled water, and the final volume was adjusted to $100 \mathrm{ml}$ with distilled water. In reducing solution, $1 \mathrm{~g}$ of $\mathrm{p}$-phenylenediamine was dissolved in $100 \mathrm{ml}$ of $3 \% \mathrm{w} / \mathrm{v}$ of sodium metabisulfite solution for reducing solution [17].

\section{Estimation of calcium phosphate by colorimetric method}

As per experimental design, the dissolution studies of calcium phosphate were carried out in six groups as like dissolution method of calcium oxalate; one group served as negative control (Group I) which containing only $1 \mathrm{mg}$ of calcium phosphate. Exactly $1 \mathrm{mg}$ of the calcium phosphate, $10 \mathrm{mg}$ standard cystone were weighed and packed as standard group (Group II). In test groups (Groups III-VI), $10 \mathrm{mg}$ each of test substances EIBL, AIBL, EIBR, and AIBR were packed along with $1 \mathrm{mg}$ of the calcium phosphate, respectively. All groups were packed as above in egg-based semipermeable membranes, allowed to suspend in separate conical flasks containing $100 \mathrm{ml}$ of $0.1 \mathrm{M}$ TRIS buffer, and were kept in an incubator, preheated to at $37 \pm 1^{\circ} \mathrm{C}$ for $7 \mathrm{~h}$. After $7 \mathrm{~h}$, flasks with membrane were kept in magnetic stirrer for $5 \mathrm{~min}$ and content of each membrane was collected in different test tubes by removing the sutures. $2 \mathrm{ml}$ of $1 \mathrm{~N}$ sulfuric acid, $2.5 \mathrm{ml}$ of molybdic sulfuric acid reagent, $1 \mathrm{ml}$ of reducing solution was added, and final volume was made to $10 \mathrm{ml}$ using distilled water. For standard calibration curve, various dilutions of calcium phosphate were prepared $(200,400,600,800$, and $1000 \mu \mathrm{g} /$ $\mathrm{ml}$ ) containing $2.5 \mathrm{ml}$ of molybdic sulfuric acid reagent, $1 \mathrm{ml}$ of reducing solution, and final volume was made up to $10 \mathrm{ml}$ using distilled water. The optical densities of standard and all the experimental groups were measured by colorimeter at $600-750 \mathrm{~nm}$ [17-19]. Each treatment was repeated 3 times and optical densities were expressed as mean \pm SD. The undissolved calcium phosphate was determined from the standard calibration curve using Microsoft Excel 2007 (Table 1 and Fig. 1). The results of the experimental groups were interpreted as percentage dissolution.

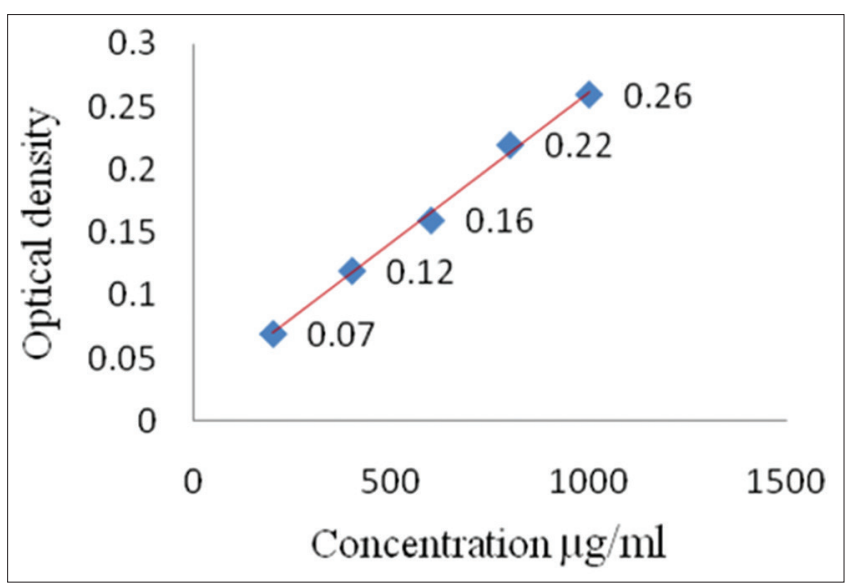

Fig. 1: Standard calibration curve of calcium phosphate 
Table 1: Standard calibration curve of calcium phosphate

\begin{tabular}{ccccc}
\hline Standard calibration curve $(\boldsymbol{\mu g} / \mathbf{m l})$ & ${\text { Molybdic } \mathbf{H}_{2} \mathbf{S O}_{4} \text { reagent }}$ & Reducing solution & Distilled water (q.s.) & Optical density \\
\hline 200 & $2.5 \mathrm{ml}$ in each & $1 \mathrm{ml}$ in each & Up to $10 \mathrm{ml}$ in each & 0.07 \\
400 & & & 0.12 \\
600 & & 0.16 & 0.22 \\
800 & & & 0.26 \\
1000 & & & \\
\hline
\end{tabular}

\section{Nucleation assay (turbidity method)}

In vitro anti-lithiatic activity was tested in terms of the inhibitory properties of the extracts on the nucleation of calcium oxalate crystals. Nucleation assay was done by following turbidity method, and nucleation of calcium oxalate crystals was determined by a spectrophotometric assay $[17,20,21]$. The method used was similar to that described by Hennequin et al. and Atmani and Khan. Solutions of calcium chloride and sodium oxalate were prepared at a final concentration of $5 \mathrm{mmol} / \mathrm{L}$ and $7.5 \mathrm{mmol} / \mathrm{L}$, respectively, in a buffer containing Tris $0.05 \mathrm{~mol} / \mathrm{L}$ and $\mathrm{NaCl} 0.15 \mathrm{~mol} / \mathrm{L}$ at $\mathrm{pH}$ 6.5; both solutions were filtered 3 times through an $0.22 \mu \mathrm{m}$ filter. About $950 \mu \mathrm{l}$ of calcium chloride solution was mixed with $100 \mu$ leach of EIBL, AIBL, EIBR, AIBR, and standard cystone at different concentrations $(100$, $200,400,800$, and $1000 \mu \mathrm{g} / \mathrm{ml}$ ). Crystallization was initiated by adding $950 \mu \mathrm{l}$ of sodium oxalate solution. The final solution was magnetically stirred at $800 \mathrm{rpm}$ for $15 \mathrm{~min}$, and the temperature was maintained at $37^{\circ} \mathrm{C}$. The optical density of the crystallized suspension was measured at $620 \mathrm{~nm}$ in spectrophotometer after addition of calcium-containing solution. All the experiments were performed in triplicate. The rate of nucleation was estimated by comparing the induction time (the delay before the appearance of crystals that have reached a critical size and thus become optically detectable) in the presence and absence of standard and test samples.

$\%$ Inhibition $=\{(\mathrm{OD}$ control $-\mathrm{OD}$ sample $) / \mathrm{OD}$ control $\} \times 100$

\section{Aggregation assay}

The aggregation of the calcium oxalate crystals was determined by the spectrophotometric assay method similar to that described by Hess et al., with slight modifications [17,20,21]. The calcium oxalate monohydrate crystals were prepared by mixing both the solutions of calcium chloride and sodium oxalate of $50 \mathrm{mmol} / \mathrm{L}$ each. The solution was equilibrated to $60^{\circ} \mathrm{C}$ in a water bath for $1 \mathrm{~h}$ and then cooled to $37^{\circ} \mathrm{C}$ overnight. The crystals were harvested by centrifugation and then evaporated at $37^{\circ} \mathrm{C}$. Calcium oxalate crystals were then buffered with $0.5 \mathrm{ml}$ of $0.05 \mathrm{~mol} / \mathrm{L}$ Tris buffer and $0.5 \mathrm{ml}$ of $0.15 \mathrm{~mol} / \mathrm{L} \mathrm{NaCl}$ solution at $\mathrm{pH} 6.5$ to a final concentration of $1 \mathrm{mg} / \mathrm{ml}$. The experiments were conducted at $37^{\circ} \mathrm{C}$ in the absence or presence of EIBL, AIBL, EIBR, AIBR, and cystone at different concentrations $(100,200,400,800$, and $1000 \mu \mathrm{g} / \mathrm{ml}$ ) with constant stirring. After stopping the stirring, optical density was measured at $620 \mathrm{~nm}$ in a spectrophotometer, and the percentage inhibition of aggregation was estimated using the same formula as in turbidity method.

\section{Statistical analysis}

The results were expressed as mean \pm SD. The difference among data was determined using one-way ANOVA followed by Dunnett's test as per suitability. $\mathrm{p}<0.05$ was considered as statistically significant, $\mathrm{p}<0.01$ was considered as very significant.

\section{RESULTS}

The yields of various extracts were found to be $7.5 \%$ (EIBL), $5.2 \%$ (AIBL), 9.4\% (EIBR), and 6.1\% (AIBR) respectively. From preliminary phytochemical screening of I. batatas, we found that the carbohydrates, glycosides, phenols, tannins, proteins and amino acids, saponins, and flavonoids were present in EIBL, EIBR, AIBL, and AIBR (Table 2).

There is inverse relationship between the dissolution of calcium oxalate and concentration of calcium ions in solutions. In the estimation of
Table 2: Qualitative chemical evaluation of $I$. batatas

\begin{tabular}{lcccc}
\hline Phytoconstituents & EIBL & AIBL & EIBR & AIBR \\
\hline Alkaloids & + & - & + & - \\
Carbohydrates & + & + & + & + \\
Glycosides & + & + & + & + \\
Phenols & + & + & + & + \\
Tannins & + & + & + & + \\
Proteins and amino acids & + & + & + & + \\
Saponins & + & + & + & + \\
Flavonoids & + & + & + & + \\
\hline
\end{tabular}

+: Present, -: Not present, EIBL: Ethanolic extract of $I$. batatas leaves,

EIBR: Ethanolic extract of $I$. batatas roots, AIBL: Aqueous extract of $I$. batatas

leaves, AIBR: Aqueous extract of I. batatas roots, I. batatas: Ipomoea batatas

calcium oxalate by titrimetry method, the ethanolic extracts of $I$. batatas leaves and roots have very significant $(\mathrm{p}<0.01)$ capability to dissolve calcium oxalate as foremost element for stone forming in the urinary tract. Percentage dissolution of calcium oxalate crystals was found to be $45.47 \%$ for cystone, $37.53 \%$ for EIBL, $22.74 \%$ for AIBL, and $39.74 \%$ and $24.28 \%$ for EIBR and AIBR, respectively (Table 3).

In the estimation of calcium phosphate by the colorimetric method, the percentage dissolution of calcium phosphate crystals by cystone, EIBL, AIBL, EIBR, and AIBR was found to be $71.94 \%, 67.15 \%, 43.17 \%, 76.74 \%$ and $47.96 \%$, respectively. The extracts of both $I$. batatas leaves and roots have very significant $(\mathrm{p}<0.01)$ capability to dissolve calcium phosphate as secondary element for stone forming in the urinary tract (Table 4)

The nucleation assay was done by turbidity method, and nucleation of calcium oxalate crystals was determined by a spectrophotometric assay. The changes in the turbidity or optical density of different concentrations of EIBL, AIBL, EIBR, AIBR, and standard cystone (100, 200, 400, 800, and $1000 \mu \mathrm{g} / \mathrm{ml}$ ) were plotted at different time intervals. The turbidity increased linearly up to $5 \mathrm{~min}$, which indicated the nucleation process and then decreased linearly up to $15 \mathrm{~min}$ indicating the aggregation process. The maximum percent inhibition of nucleation of calcium oxalate by EIBL, AIBL, EIBR, AIBR, and cystone was found to be $59.09 \%, 50.0 \%$, $84.09 \%, 47.73 \%$, and $81.82 \%$, respectively, at $1000 \mu \mathrm{g} / \mathrm{ml}$ (Table 5).

The aggregation of the calcium oxalate crystals was determined by the spectrophotometric assay method. The crystals in solution stick together to form large particles called as aggregates. The maximum percentage inhibition of calcium oxalate aggregation by EIBL, AIBL, EIBR, AIBR, and cystone were found to be $63.46 \%, 36.54 \%, 84.61 \%, 42.3 \%$, and $82.69 \%$, respectively, at $1000 \mu \mathrm{g} / \mathrm{ml}$ (Table 6). I. batatas extracts and standard cystone were very significantly $(\mathrm{p}<0.01)$ inhibited both the nucleation and aggregation of calcium oxalate crystals (Table 6).

\section{DISCUSSION}

The supersaturation of urine with calcium oxalate, the most common component of kidney stones, attributes to calcium oxalate particles crystallization within the urinary tract with later factors being nucleation, growth, and aggregation. Thus, if supersaturation or later steps in crystallization can be prevented, then lithiasis should be avoided. Although several measures are usually taken to reduce supersaturation such as increasing fluid intake and medical therapy, it is generally accepted that better strategies for preventing kidney stones need to be developed [22-24]. Nucleation is an important first step for 
the initiation of crystals, which then grow and form aggregates. Calcium oxalate crystals begin grow, aggregate with other crystals, and retained in the kidney. This is aggregation process which causes renal injury [25]. Stone crystals bind to one another through a process known as aggregation promoted by strong chemicals and electrical forces. Adhered crystals were held in place and cannot be easily separated, and this plays an important role in lithiasis [26]. In this in vitro study, the dissolution methods of calcium oxalate and calcium phosphate were used to know the role of $I$. batatas extracts in dissolving the already formed stones nucleus in renal system. As in vitro crystallization study was performed, since the results clearly indicate that the crystal nucleation and aggregation were found to express a concentration-dependent inhibition. Sweet potatoes are a nutritious food, low in fat, and protein but rich in carbohydrate. Both tubers and leaves are good sources of antioxidants, fiber, zinc, potassium, sodium, manganese, calcium, magnesium, iron, and Vitamin C $[27,28]$. Due to the presence of various kind of physiologically active components in both the roots and leaves of sweet potato have potential to maintain human health and mitigate many diseases [29].The EIBL and EIBR were shown the maximum percentage of dissolution for the already formed calcium oxalate and calcium phosphate crystals than that of AIBL and AIBR (Tables 3 and 4). The maximum inhibition was recorded for EIBL and EIBR in nucleation and aggregation assays which have shown the remarkable anti-lithiatic activity which was more than that of both aqueous extracts of leaves and roots (Tables 5 and 6). The studies of nucleation and aggregation assay have a great scope to study the mechanism of action of drugs having anti-lithiatic potential. Thus, this study puts forth the possibility of using I. batatas as therapeutic agents to treat urolithiasis.

\section{CONCLUSION}

The results clearly indicate that, under in vitro conditions, EIBL and EIBR were found to express a concentration-dependent inhibition on the crystal nucleation and aggregation. The ethanolic extracts were also having more capacity to dissolve the already formed kidney stones. These findings substantiate the traditional use of the I. batatas in the treatment of urinary stones and kidney problems. To substantiate its

Table 3: Effect of I. batatas on percentage dissolution of calcium oxalate crystals

\begin{tabular}{lccc}
\hline $\begin{array}{l}\text { Experimental } \\
\text { design }\end{array}$ & Volume of standard KMNO & Wt. of calcium estimated (mg) & Wt. of calcium reduced (mg) \\
\hline Group I & $4.53 \pm 0.06$ & 0.8598 & - \\
Group II & $2.47 \pm 0.15^{*}$ & 0.4688 & 0.3909 \\
Group III & $2.83 \pm 0.12^{*}$ & 0.5371 & 0.3226 \\
Group IV & $3.51 \pm 0.1^{*}$ & 0.6643 & 0.1954 \\
Group V & $2.73 \pm 0.06^{*}$ & 0.5182 & 0.3416 \\
Group VI & $3.43 \pm 0.58^{*}$ & 0.6510 & 0.2088 \\
\hline
\end{tabular}

Volume of $\mathrm{KMNO}_{4}$ was expressed as mean $\pm \mathrm{SD}$; ${ }^{*} \mathrm{p}<0.01$ was considered as very significant when compared with control Group I (n=3), I. batatas: Ipomoea batatas

Table 4: Effect of I. batatas on percentage dissolution of calcium phosphate crystals

\begin{tabular}{|c|c|c|c|c|c|c|c|}
\hline $\begin{array}{l}\text { Experimental } \\
\text { design }\end{array}$ & $\begin{array}{l}\text { Molybdic } \\
\mathrm{H}_{2} \mathrm{SO}_{4} \text { reagent }\end{array}$ & $\begin{array}{l}\text { Reducing } \\
\text { solution }\end{array}$ & $\begin{array}{l}\text { Distilled } \\
\text { water (q.s.) }\end{array}$ & $\begin{array}{l}\text { Optical } \\
\text { density }\end{array}$ & $\begin{array}{l}\text { Wt. of calcium } \\
\text { estimated (mg) }\end{array}$ & $\begin{array}{l}\text { Wt. of calcium } \\
\text { reduced (mg) }\end{array}$ & $\begin{array}{l}\text { Percentage } \\
\text { dissolution }\end{array}$ \\
\hline Group I & $2.5 \mathrm{ml}$ in each & $1 \mathrm{ml}$ in each & Up to $10 \mathrm{ml}$ in each & $0.21 \pm 0.01$ & 0.8657 & - & - \\
\hline Group II & & & & $0.08 \pm 0.02 *$ & 0.2429 & 0.6228 & 71.94 \\
\hline Group III & & & & $0.09 \pm 0.01^{*}$ & 0.2844 & 0.5813 & 67.15 \\
\hline Group IV & & & & $0.14 \pm 0.006^{*}$ & 0.4920 & 0.3737 & 43.17 \\
\hline Group V & & & & $0.07 \pm 0.005^{*}$ & 0.2014 & 0.6643 & 76.74 \\
\hline Group VI & & & & $0.13 \pm 0.006^{*}$ & 0.4505 & 0.4152 & 47.96 \\
\hline
\end{tabular}

The optical densities were expressed as mean $\pm \mathrm{SD} ;{ }^{*} \mathrm{p}<0.01$ was considered as very significant when compared with control Group I (n=3), I. batatas: Ipomoea batatas

Table 5: Inhibitory effect of $I$. batatas on nucleation assay

\begin{tabular}{|c|c|c|c|c|c|}
\hline \multirow[t]{2}{*}{ Concentrations $(\mu \mathrm{g})$} & \multicolumn{5}{|c|}{ Optical densities (percentage inhibition) } \\
\hline & EIBL & AIBL & EIBR & AIBR & Cystone \\
\hline $100 \mu \mathrm{g} / \mathrm{ml}$ & $0.39 \pm 0.01 *(11.36 \%)$ & $0.41 \pm 0.03(6.81 \%)$ & $0.37 \pm 0.01 *(15.91 \%)$ & $0.42 \pm 0.02(4.55 \%)$ & $0.36 \pm 0.02 *(18.18 \%)$ \\
\hline $400 \mu \mathrm{g} / \mathrm{ml}$ & $0.25 \pm 0.05 *(43.18 \%)$ & $0.31 \pm 0.01 *(29.54 \%)$ & $0.22 \pm 0.07 *(50.0 \%)$ & $0.29 \pm 0.02 *(34.09 \%)$ & $0.21 \pm 0.06^{*}(52.27 \%)$ \\
\hline $800 \mu \mathrm{g} / \mathrm{ml}$ & $0.21 \pm 0.02 *(52.27 \%)$ & $0.26 \pm 0.02 *(40.91 \%)$ & $0.19 \pm 0.01 *(56.82 \%)$ & $0.25 \pm 0.01 *(43.18 \%)$ & $0.17 \pm 0.05^{*}(61.36 \%)$ \\
\hline $1000 \mu \mathrm{g} / \mathrm{ml}$ & $0.18 \pm 0.06 *(59.09 \%)$ & $0.22 \pm 0.02 *(50.0 \%)$ & $0.07 \pm 0.05 *(84.09 \%)$ & $0.23 \pm 0.03 *(47.73 \%)$ & $0.08 \pm 0.01 *(81.82 \%)$ \\
\hline
\end{tabular}

The optical densities were expressed as mean \pm SD; ${ }^{*} \mathrm{p}<0.01$ was considered as very significant when compared with control OD - 0.44 \pm 0.01 , EIBL: Ethanolic extract of I. batatas leaves, EIBR: Ethanolic extract of I. batatas roots, AIBL: Aqueous extract of I. batatas leaves, AIBR: Aqueous extract of $I$. batatas roots, I. batatas: Ipomoea batatas

Table 6: Inhibitory effect of $I$. batatas on aggregation assay

\begin{tabular}{|c|c|c|c|c|c|}
\hline \multirow[t]{2}{*}{ Concentrations $(\mu \mathrm{g})$} & \multicolumn{5}{|c|}{ Optical densities (percentage inhibition) } \\
\hline & EIBL & AIBL & EIBR & AIBR & Cystone \\
\hline $100 \mu \mathrm{g} / \mathrm{ml}$ & $0.43 \pm 0.01 *(17.3 \%)$ & $0.48 \pm 0.03(7.69 \%)$ & $0.42 \pm 0.02 *(19.23 \%)$ & $0.47 \pm 0.04(9.62 \%)$ & $0.39 \pm 0.03 *(25.0 \%)$ \\
\hline $200 \mu \mathrm{g} / \mathrm{ml}$ & $0.36 \pm 0.02 *(30.77 \%)$ & $0.4 \pm 0.02 *(23.08 \%)$ & $0.35 \pm 0.02 *(32.69 \%)$ & $0.39 \pm 0.01 *(25.0 \%)$ & $0.27 \pm 0.02 *(48.07 \%)$ \\
\hline $400 \mu \mathrm{g} / \mathrm{ml}$ & $0.28 \pm 0.05 *(46.15 \%)$ & $0.39 \pm 0.02 *(25.0 \%)$ & $0.24 \pm 0.03 *(53.84 \%)$ & $0.37 \pm 0.02 *(28.4 \%)$ & $0.21 \pm 0.03 *(59.61 \%)$ \\
\hline $800 \mu \mathrm{g} / \mathrm{ml}$ & $0.24 \pm 0.03 *(53.85 \%)$ & $0.36 \pm 0.03 *(30.77 \%)$ & $0.19 \pm 0.01 *(63.46 \%)$ & $0.31 \pm 0.01 *(40.38 \%)$ & $0.17 \pm 0.02 *(67.3 \%)$ \\
\hline $1000 \mu \mathrm{g} / \mathrm{ml}$ & $0.19 \pm 0.04 *(63.46 \%)$ & $0.33 \pm 0.01 *(36.54 \%)$ & $0.08 \pm 0.04 *(84.61 \%)$ & $0.3 \pm 0.02 *(42.3 \%)$ & $0.09 \pm 0.02 *(82.69 \%)$ \\
\hline
\end{tabular}

The optical densities were expressed as mean \pm SD; ${ }^{p} \mathrm{p}<0.01$ was considered as very significant when compared with control OD - 0.52 \pm 0.01 , EIBL: Ethanolic extract of $I$. batatas leaves, EIBR: Ethanolic extract of $I$. batatas roots, AIBL: Aqueous extract of $I$. batatas leaves, AIBR: Aqueous extract of $I$. batatas roots,

I. batatas: Ipomoea batatas 
in vitro effect, the in vivo studies need to be carried out in experimental animals, then this drug can be used for the treatments of kidney stone.

\section{REFERENCES}

1. Coe F, Parks J. Pathophysiology of kidney stones and stratergies for treatment. Hosp Pract 1983;23:145-68.

2. Sunitha J, Asha S, Taju G. Protective effect of Spirulina on ethylene glycol induced urolithiasis in rats. Int Res J Pharm 2012;3:444-8.

3. Kishimoto T, Yamamoto K, Sugimoto T, Yoshihara H, Maekawa M. Side effects of extracorporeal shock-wave exposure in patients treated by extracorporeal shock-wave lithotripsy for upper urinary tract stone. Eur Urol 1986;12:308-13.

4. Christina AJ, Muthumani P. Phytochemical investigation and anti lithiatic activity of Abelmoschus moschatus medikus. Int J Pharm Pharm Sci 2013;5:108-13.

5. Pak CY. Prevention and treatment of kidney stones. Role of medical prevention. J Urol 1989;141:798-801.

6. Alok S, Jain SK, Verma A, Kumar M, Sabharwal M. Pathophysiology of kidney, gallbladder and urinary stones treatment with herbal and allopathic medicine: A review. Asian Pac J Trop Dis 2013;3:496-504.

7. Dahanukar A, Kulkarni RA, Rege NN. Pharmacology of medicinal and natural products. Indian J Pharm 2000;32:81-118.

8. Hue SM, Boyce AN, Somasundram C. Comparative study on the antioxidant activity of leaf extract and carotenoids extract from Ipomoea batatas var. Oren (Sweet potato) Leaves. World Acad Sci Eng Technol 2011;58:584-7.

9. Ojong PB, Njiti V, Guo Z, Gao M, Besong S, Barnes SL. Variation of flavonoid content among sweet potato accessions. J Am Soc Hortic Sci 2008; 133:819-24.

10. Islam S, Yoshimoto Y, Yamakawa O. Distribution and physiological function of caffeoylquinic acid derivatives in sweet potato genotypes. J Food Sci 2003;68:111-6.

11. Anbuselvi S, Muthumani S. Phytochemical and antinutritional constituents of sweet potato. J Chem Pharm Res 2014;6:380-3.

12. Warrier PK, Nambiar VP, Ramankutty C. Arya Vaidya Sala. Indian Medicinal Plants. Vol. 3. New Delhi: Orient Longman Publication; 1995. p. 218

13. Sivasankari B, Anandharaj M, Gunasekaran P. An ethnobotanical study of indigenous knowledge on medicinal plants used by the village peoples of Thoppampatti, Dindigul district, Tamilnadu, India. J Ethnopharmacol 2014;153:408-23.

14. Gupta S, Mukherjee M, Kumar R. Some medicinal and aromatic plants from the districts of west Bengal used in the treatment of kidney stones along with their status. Int J Pharm Res Health Sci 2015;3:661-8.

15. Pochapski MT, Fosquiera EC, Esmerino LA, Dos Santos EB, Farago PV, Santos FA, et al. Phytochemical screening, antioxidant, and antimicrobial activities of the crude leaves' extract from Ipomoea batatas (L.) lam. Pharmacogn Mag 2011;7:165-70.

16. Khandelwal KR. Practical Pharmacognosy Techniques and Experiments. $10^{\text {th }}$ ed. Pune: Nirali Prakashan; 2003. p. 140-57.

17. Phatak RS, Hendre AS. In-vitro antiurolithiatic activity of Kalanchoe pinnata extract. Int J Pharmacogn Phytochem Res 2015;7:275-9.

18. Khare P, Mishra VK, Arun K, Bais N, Singh R. Study on in vitro activity of Phyllanthus niruri linn. Leaves by homogenous precipitation and turbiditory method. Int J Pharm Pharm Sci 2014;6:124-7.

19. Bawane P, Jain M, Gawad J, Godad A, Tauro S. Evaluation of polyherbal extracts for In-Vitro antiurolithiatic activity using bioenhancer. Eur J Biomed Pharm Sci 2014;1:480-9.

20. Atmani F, Khan SR. Effects of an extract from Herniaria hirsuta on calcium oxalate crystallization in vitro. BJU Int 2000;85:621-5.

21. Saha S, Verma RJ. Inhibition of calcium oxalate crystallization in vitro by an extract of Bergenia ciliata. Arab J Urol 2013;11:187-92.

22. Basavaraj DR, Biyani CS, Browning AJ, Cartledge JJ. The role of urinary kidney stone inhibitors and promoters in the pathogenesis of calcium containing renal stones. EAU-EBU Update Ser 2007;5:126-36.

23. Consensus conference. Prevention and treatment of kidney stones. JAMA 1988;260:977-81

24. Khan SR. Structure and development of calcific urinary stones. In: Bonucci E, editor. Calcification in Biological Systems. Boca Raton: CRC Press; 1992. p. 345-63.

25. Patel MA, Patel PK, Seth AK. Inhibition of calcium oxalate crystallization by the fruit extracts of Piper nigrum L. Pharm Online 2011;2:1169-77.

26. Kalpana S, Nirmaladevi R, Shrinidhi Rai T, Karthika P. Inhibition of calcium oxalate crystallization in vitro by extract of banana cultivar monthan. Int J Pharm Pharm Sci 2013;5:649-53.

27. Teow CC, Truong VD, McFeeters RF, Thompson RL, Pecota KV, Yencho GC. Antioxidant activities, phenolic and carotene contents of sweet potato genotypes with varying flesh colors. Food Chem 2007;103:829-38.

28. Antia BS, Akpan EJ, Okon PA, Umoren IU. Nutritive and anti-nutritive evaluation of sweet potatoes (Ipomoea batatas) leaves. Pak J Nutr 2006;5:166-8.

29. Yoshimoto M, Okuno S, Yoshinaga M, Yamakawa O, Yamaguchi M, Yamada J, et al. Antimutagenicity of sweetpotato (Ipomoea batatas) roots. Biosci Biotechnol Biochem 1999;63:537-41. 